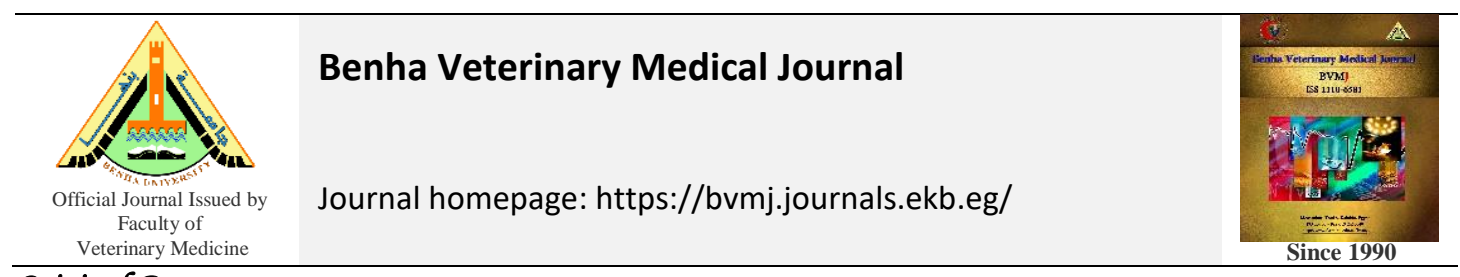

Original Paper

\title{
Prevalence of multi-drug resistant Escherichia coli in diarrheic ruminants
}

Ashraf Abd El-Tawab ${ }^{1}$, Fatma El-Hofy ${ }^{1}$, Ahmed El Hamalawy²,Amged Abo-Ela ${ }^{3}$, Wafaa El-Shazly ${ }^{3}$, Manar E. El-khayat ${ }^{1}$

1 Bacteriology, Immunology and Mycology Department, Faculty of Veterinary Medicine, Benha University, Egypt.

2Physics Department, Faculty of Science, Menofyia University, Egypt.

3Animal Production Research Institute, Agriculture Research Center (ARC),Egypt.

\begin{tabular}{|c|c|}
\hline ARTICLE INFO & ABSTRACT \\
\hline $\begin{array}{l}\text { Received 29/02/2020 } \\
\text { Accepted 29/03/2020 } \\
\text { Availa6le On-Line } \\
\text { 18/07/2020 }\end{array}$ & $\begin{array}{l}\text { Escherichia coli }(E \text {. coli) is the most significant cause of neonatal diarrhea in ruminants. The } \\
\text { current study was designed to monitor the prevalence of multi-drug (MDR) resistant } E \text {. coli } \\
\text { in diarrheic ruminants in Egypt. Rectal swab samples }(\mathrm{n}=150) \text { were collected between } \\
\text { November } 2018 \text { and April } 2019 \text { from diarrheic calves }(\mathrm{n}=35) \text {, lambs }(\mathrm{n}=35) \text { and goat kids } \\
(\mathrm{n}=80) \text { up to } 3 \text { months from Gimmeza animal production researches station, Agriculture } \\
\text { Research Centre (ARC), Egypt. Samples were submitted for isolation and identification of } E \text {. } \\
\text { coli by conventional culture methods. From the examined samples, } 82(54.67 \%) \text { were } \\
\text { positive for } E \text {. coli. Among the E. coli isolates, } 48 \text { were identified as pathogenic E. coli by } \\
\text { cultivation on Congo Red Agar and were submitted for antibiogram. Sensitivity tests } \\
\text { revealed that } 10 / 48 \text { ( } 20.83 \%) \text { isolates were MDR. The } 10 \text { MDR E. coli isolates were } \\
\text { serologically identified as } \mathrm{O}_{157}: \mathrm{H}_{7} \text { ( } \mathrm{n}=4 \text {; two isolated from calves and two from goat kids), } \\
\mathrm{O}_{125} \text { (n=3; two isolated from calves and one from lambs), } \mathrm{O}_{44}(\mathrm{n}=3 \text {; two isolated from goat } \\
\text { kids and one from lambs). }\end{array}$ \\
\hline
\end{tabular}

\section{INTRODUCTION}

Diarrhea is the principal cause of mortality and high morbidity in young animals causing massive economic and productive losses to livestock industry globally (Zahra et al., 2019). About $57 \%$ of weaning calf mortalities were due to diarrhea according to National Animal Health Monitoring System (Cho and Yoon, 2014). In Egypt, Neonatal calf diarrhea is considered the major reason of calf mortality. It represents about $27.4-55.0 \%$ of the total deaths in young calves (El Seedy et al., 2016).

Diarrhea has multifactorial causes including infectious as well as non-infectious factors related to the animal incorrect management, feeding, immunological status and animal breed (Hosein, 2019). Infectious diarrhea is the most significant cause of mortality in neonatal ruminants. It can be caused by many pathogens including viruses (coronavirus and rotavirus), protozoa (Cryptosporidium parvum) and bacteria (enterotoxigenic Escherichia coli (ETEC) and Salmonellae are the most economically important pathogens) (Izzo et al., 2011).

Entero-toxigenic E. coli is considered the most common cause of neonatal diarrhea. It produces different virulence factors including, colonization in small intestine, avoiding the immune response and stimulating the deleterious inflammatory response (Muluken et al., 2017). Escherichia coli causes calf coli septicemia, diarrhea in lambs and earlyweaned piglets (Yu et al., 2011) and hemorrhagic colitis, hemorrhagic uremic syndrome and thrombotic thrombocytopenic purpura in humans (Pearce et al., 2004). Escherichia coli is a Gram negative, rod shaped flagellated, nonsporulating and facultative anaerobic bacterium belongs to family Enterobacteriaceae. This bacterium is classified into several categories based on its virulence factors such as ETEC, attaching and effacing Escherichia coli (AEEC), enteropathogenic E. coli (EPEC), enterohaemorrhagic $E$. coli (EHEC) and shiga toxin producing E. coli (STEC) (Wang et al., 2010).

Antibiotics are widely used in veterinary medicine to control bacterial infections. During treatment of dairy cows, the milk used to feed calves could be contaminated with antimicrobial residues (Deng et al., 2017; Leão et al., 2017). Bacteria can develop antimicrobial resistance at subminimum inhibitory concentrations, (Francisco et al., 2019). Antibiotic resistant bacteria carried by animals can enter the human food chain through the consumption of meat or other animal products, through farm run-off water and by other pathways (Collignon et al., 2005).

The present study was designed to monitor the prevalence of pathogenic E. coli in diarrheic calves, lambs and goat kids younger than 3 months with determination of the resistance profile of the pathogenic $E$. coli to different antibiotics

\footnotetext{
* Corresponding author: Manar E. El-khayat, Bacteriology, Immunology and Mycology Department, Faculty of Veterinary Medicine, Benha University, Egypt.
} 


\section{MATERIAL AND METHODS}

\subsection{Samples}

Rectal swabs $(\mathrm{n}=150)$ were collected between November 2018 and April 2019 from diarrheic cases of calves $(n=35)$, lambs $(n=35)$ and goat kids $(n=80)$ up to 3 months from Gimmeza animal production researches station, Agriculture Research Center, Egypt. Each swab was inoculated into 5 $\mathrm{ml}$ of sterile buffered peptone water then tightly closed, labeled and transported immediately to the laboratory in an ice container.

2.2. Isolation and identification of E. coli:

It was performed according to Quinn et al. (2002). Swabs were inoculated into $5 \mathrm{ml}$ nutrient broth (Oxiod) and incubated at $37{ }^{\circ} \mathrm{C}$ for $18-24 \mathrm{hrs}$., followed by sub-culturing onto MacConkey's agar (Oxiod) and incubated at $37{ }^{\circ} \mathrm{C}$ for $24 \mathrm{hrs}$. Lactose fermenter colonies were picked up and streaked onto EMB agar (Oxiod). Suspected E. coli isolates were indicated by the appearance of the characteristic green metallic sheen colonies.

\subsection{Biochemical identification of E. coli isolates:}

It was performed according to Quinn et al. (2002) by oxidase, lactose fermentation, indole production methyl red, Vogues Proskauer, citrate utilization, $\mathrm{H}_{2} \mathrm{~S}$ production, urea hydrolysis and catalase tests.

\subsection{Detection of pathogenicity:}

It was performed according to Ruchi et al. (2015) by cultivation of E. coli isolates on Congo Red Agar medium (Berkoff and Vinal, 1986).

\subsection{In vitro antibiotic sensitivity of $E$. coli isolates:}

It was performed by disc diffusion method according to Finegold and Martin (1982) and CLSI (2016). The antimicrobial discs (Oxiod, UK) that used for sensitivity testing of E. coli were Amoxicillin + Clavulinic acid (30 $\mu \mathrm{g})$, Cefotaxime $(30 \mu \mathrm{g})$, Ciprofloxacin $(5 \mu \mathrm{g})$, Gentamicin $(10 \mu \mathrm{g})$, Erythromycin $(15 \mu \mathrm{g})$, Ampcillin $(30 \mu \mathrm{g})$, Chloramphenicol $(10 \mu \mathrm{g})$, and Oxytetracycline $(30 \mu \mathrm{g})$.

2.6. Serotyping of MDR pathogenic E. coli isolates:

Ten multi-drugs resistant pathogenic $E$. coli isolates were sero-grouped in Animal Health Research Institute, Dokki, Egypt according to Kok et al. (1996) by using the commercially available rapid diagnostic E.coli antisera $(E$. coli antisera set 1 for $\mathrm{O}$ antigen- $E$. coli antisera set 2 for $\mathrm{H}$ antigen) (DENKA SEIKEN Co., Japan).

\section{RESULTS}

From the examined samples $(\mathrm{n}=150), 82(54.67 \%)$ were positive for E. coli. Among the $82 E$. coli isolates, 48 were identified as pathogenic $E$.coli by cultivation on Congo Red Agar as shown in table (1).

To assess the resistance profile, the 48 pathogenic E. coli isolates were submitted for antibiogram sensitivity tests, showed that $85 \%$ were resistant to Oxytetracycline followed by Ampicillin $83 \%$, Chloramphenicol $60 \%$ and cefotaxime $20 \%$ but no resistance to Amoxicillin + clavulanic acid, Ciprofloxacin, Gentamicin, and Erythromycin. Among $E$. coli isolates, 10 isolates $(20.83 \%)$ were found to be multidrug resistant to three or more antibiotic groups.

The 10 MDR E. coli isolates were serologically identified as described in table (3).

\begin{tabular}{lccccc}
\multicolumn{6}{l}{ Table 1 Prevalence of pathogenic E. coli isolated from fecal samples } \\
\hline Animal & $\begin{array}{c}\text { No of } \\
\text { fecal } \\
\text { samples }\end{array}$ & $\begin{array}{c}\text { No. } \\
\text { pathogenic } E . \\
\text { coli isolates }\end{array}$ & $\begin{array}{c}\text { No. non- } \\
\text { pathogenic } E . \\
\text { coli isolates }\end{array}$ & $\begin{array}{c}\text { Total } \\
\text { No. E.coli } \\
\text { isolates }\end{array}$ & $\% *$ \\
\hline Calves & 35 & 16 & 12 & 28 & $80 \%$ \\
Goat kids & 80 & 23 & 16 & 39 & $\begin{array}{c}48.7 \\
\% \\
\text { lambs }\end{array}$ \\
\hline Total & 35 & 9 & 6 & 15 & $\begin{array}{c}42.8 \\
\%\end{array}$ \\
\hline * Percentage in relation to the total number of faecal samples of each animal species. &
\end{tabular}

Table 2 Antibiotic sensitivity for the 48 pathogenic E. coli isolates by disc diffusion method

\begin{tabular}{|c|c|c|c|c|c|}
\hline $\begin{array}{l}\text { Antimicrobial } \\
\text { agent }\end{array}$ & Conc & $\begin{array}{c}\text { Sensitiv } \\
\mathrm{e}\end{array}$ & $\begin{array}{c}\text { Intermediat } \\
\mathrm{e}\end{array}$ & $\begin{array}{c}\text { Resistan } \\
\mathrm{t}\end{array}$ & $\begin{array}{c}\% \text { of } \\
\text { resistance } \\
*\end{array}$ \\
\hline Amoxicillin+ & 30 & 17 & 31 & - & $0 \%$ \\
\hline Clavulanic acid & $\mu \mathrm{g}$ & & & & \\
\hline Ampicillin & 10 & 2 & 6 & 40 & $83 \%$ \\
\hline Cefotaxime & $\begin{array}{l}\mu \mathrm{g} \\
30 \\
\mu \mathrm{g}\end{array}$ & 18 & 20 & 10 & $20 \%$ \\
\hline $\begin{array}{l}\text { Chloramphenico } \\
1\end{array}$ & $\begin{array}{l}30 \\
\mu \mathrm{g}\end{array}$ & 3 & 16 & 29 & $60 \%$ \\
\hline Ciprofloxacin & $5 \mu \mathrm{g}$ & 22 & 26 & - & $0 \%$ \\
\hline Erythromycin & $\begin{array}{l}15 \\
\mu \mathrm{g}\end{array}$ & 28 & 20 & - & $0 \%$ \\
\hline Gentamicin & $\begin{array}{l}10 \\
\mu \mathrm{g}\end{array}$ & 34 & 14 & - & $0 \%$ \\
\hline Oxytetracycline & $\begin{array}{l}30 \\
\mu \mathrm{g}\end{array}$ & - & 6 & 41 & $85 \%$ \\
\hline \multicolumn{6}{|c|}{$\begin{array}{l}\mu \mathrm{g} \\
\text { * Percentage in relation to the } 48 \text { pathogenic } E \text {. coli isolates submitted to the antibiot } \\
\text { sensitivity test. }\end{array}$} \\
\hline \multicolumn{4}{|c|}{ Animal $\quad$ Isolated serogroup } & \multicolumn{2}{|c|}{ No. of isolates } \\
\hline Calves & \multicolumn{3}{|c|}{$2 \mathrm{O}_{157: \mathrm{H} 7} / 2 \mathrm{O}_{125}$} & \multicolumn{2}{|c|}{4} \\
\hline Goat kids & \multicolumn{3}{|c|}{$2 \mathrm{O}_{157: \mathrm{H}} / 2 \mathrm{O}_{44}$} & \multicolumn{2}{|c|}{4} \\
\hline Lambs & \multicolumn{3}{|c|}{$1 \mathrm{O}_{44} / 1 \mathrm{O}_{125}$} & \multicolumn{2}{|c|}{2} \\
\hline Total & & & & & \\
\hline
\end{tabular}

\section{DISCUSSION}

Diarrhea is the principal cause of mortality in young animals causing massive economic and productivity losses globally (Zahra et al., 2019). In developing countries, diarrheagenic $E$. coli is the cause of large proportion of diarrhea (Clarke, 2001). In the present study, E. coli was isolated in prevalence of $80 \%$ from Calves $(n=28 / 35)$ that agreed with Shahrani et al. (2014), El-Seedy et al. (2016) as $76.45 \%$ and $75.6 \%$, respectively. But, Abu El-Ella et al. (2013) $57.1 \%$, Islam et al. (2015) 57\%, Olagun et al. (2016) $63.2 \%$ and Aref et al. (2018) 58.5\%. In contrast, Zahra et al. (2019), who isolated $E$. coli from calves with higher percentage 100\%, and Izzo et al. (2011), Masud et al. (2012), El-Shehdi et al. (2013), Hakim et al. (2017) and Safaa et al. (2019), who isolated $E$. coli from calves with lower percentage as $17.4 \%, 44 \%, 35.8 \%, 24.1 \%, 46.4 \%$, respectively.

Escherichia coli was isolated in prevalence of $48.7 \%$ from Goat kids and $42.8 \%$ from lambs that didn't agree with Fuente et al. (2002), who isolated E. coli in diarrheic animals at prevalence of $66.7 \%, 100 \%$ from (goat kids, lambs) and from calves, respectively, which were higher than those found in healthy animals (33.3-40.6\%) from (goat kids, lambs) and calves, respectively. On other hand, Orden et al. (2002) isolated E. coli in lower percentage $24.4 \%$ and $16.2 \%$ from healthy lambs and goat kids, respectively. It was detected in $3.1 \%$ and $5.9 \%$ of the diarrheic lambs and goat kids, respectively. Osman et al. (2013) recorded that E. coli prevalence rate in the diarrheic animals was $63.6 \%$ in calves, 
$27.3 \%$ in goat and $9.1 \%$ in sheep. This variation in the prevalence of $E$. coli may be attributed to difference in geographical distribution, age of calves, weather, managements and hygiene measurements.

Antibiotics are widely used for control bacterial infections in human and veterinary medicine and also used as growth promoter (Sarmah et al., 2006). Antimicrobial resistance occurs when bacteria are exposed to antimicrobial drugs. It may be irreversible, even if organism is no longer exposed to antimicrobial drug (Sundsfjord et al., 2004).

In this study, antibiotic sensitivity for 48 pathogenic E. coli isolates showed that $85 \%$ were resistant to Oxytetracycline followed by Ampicillin 83\%, Chloramphenicol 60\% and cefotaxime $20 \%$ but no resistance to Gentamicin, Ciprofloxacin, Amoxicillin + clavulanic acid and Erythromycin. Among those E. coli isolates, 10 isolates were found to be MDR to 3 or more antibiotic groups. This may be due to miss use of antibiotics or change in microbial genetic structure and metabolism (Boskovic et al., 2013). About $85 \%$ of $E$.coli isolates were resistant to Oxytetracycline, this result is slightly lower than that Karzmarczyk et al. (2011) and Masud et al. (2012), who obtained $99 \%$ and $100 \%$, respectively. Moreover, the results were higher than Srivani et al. (2017), Kohansal and Aasd et al. (2018) and Aasmae et al. (2019), who obtained $63.2 \%$, $65 \%$ and $32 \%$, respectively.

In our study, resistant to Ampicillin was $83 \%$ that agreed with Karzmarczyk et al. (2011), Kohansal and Aasd et al. (2018) and Mohamed et al. (2018), who detected 82\%, 73\%, and $83 \%$ resistance to Ampicillin, respectively. While Srivani et al. (2017) and Gupta et al. (2018), obtained lower resistance $11 \%$ and $55 \%$, respectively. In contrast, sensitivity to Gentamicin was $100 \%$ which agreed with Srivani et al. (2017) who detected $96 \%$ sensitivity and disagreed with Sun et al. (2012) and Badi et al. (2018), who reported 51.8 and $75 \%$ resistance to Gentamicin, respectively.

Sensitivity to Ciprofloxacin was $100 \%$ that agreed with Gupta et al. (2018), who reported $100 \%$ and slightly lower than Masud et al. (2012), who reported that sensitivity \% was 91. Sensitivity to Amoxicillin + clavulanic acid was $100 \%$. On other hand, Ammar et al. (2017) reported that 100 $\%$ of $E$. coli was resistance to Amoxicillin + clavulanic acid. Serologically, E. coli is divided into serogroups and serotypes on basis of their antigenic structures (Griffin and Tauxe, 1991). In this study, Serotyping of ten MDR pathogenic E.coli isolates were done and the results showed that: $4 / 10$ isolates were $\left(O_{125}\right)$ which agreed with Mosaad et al. (2008), Hakim et al. (2017), and Safaa et al. (2019). 2/10 isolates were $\left(O_{44}\right)$ that agreed with Mohamed et al. (2018) and Safaa et al. (2019). 4/10 isolates were (O157:H7), which agreed with Mosaad et al. (2008), Dastmalchi and Ayremlou (2012), Shahrani et al. (2014) and Maryam and Ali (2018).

\section{CONCULSION}

Neonatal diarrhea caused by pathogenic E. coli is a perilous problem for young animals including calves, lambs and goat kids younger than 3 months of age specially with the emergence of multidrug resistance strains

\section{REFERENCES}

1. Abd El-Hameid, Z. M. 2013. Assessment of the Hygienic Aasmae, B.; Hakkinen, L.; Kaart, T. and Kalmuss, P. (2019): Antimicrobial resistance of Escherichia coli and Enterococcus spp.isolate from Estonian cattle and swine from 2010 to 2015. Acta.Vet. Scand.,61(1): 5

2. Abou El-Ella G. A., Amr M Mohamed, A A Aame (2013): Associated with neonatal calf scour in cattle and buffalo calves using (fastest $®$ strips) rapid field test. Assiut Vet. Med. J. 59 (138):19-26.

3. Mohammed, A.S.; Mokhtaria, K.; Amar, A.A.; Tahar, B.B and Moulay, D. (2017): Chemical composition and antibacterial activity of cinnamon mumaromaticum essential oil against four enteropathogenic bacteria associated with neonatal calve diarrhea. Asian journal of animal and veterinary advances (1): 24-30

4. Nasr-Eldin, A. M; Abdel-Raheem, A.A.; Kamaly, H.F. and Hussien, S.Z. (2018): Clinical and sero-molecular characterization of Escherichia coli with an emphasis on hybrid strain in healthy and diarrheic neonatal calves in Egypt. Open Vet J. 8(4): 351-359.

5. Badi, S.; Cremonesi, P.; Abbassi, M.S. and Ibrahim, C. (2018): Antibiotic resistance phenotypes and virulence-associated genes in Escherichia coli isolated from animals and animal food product in Tunisia. FEMS Microbiology Letters (FEMS Microiol Let, Publisher: Oxfor University Pr), 365 (10)

6. Boskovic, M.; Baltic, Z.M.; Ivanovic, J.; Djuric, J.; Loncina, J.; Dokanovic M. and Markovic, R. (2013): Use of essential oils in order to prevent food-born illnesses caused by pathogens in meat. Tehn. Mesa., 54: 14-20

7. Cho, Y.I. and Yoon J. (2014): An overview of calf diarrhea infectious etiology, diagnosis, and intervention. J. Vet. Sci. 15(1):1-17

8. Clarkeb, S.C. (2001): Diarrhagenic Escherichia coli-An Emerging Problem. Diagnosis Microbiology and Infectious Disease, 41(3);938.

9. Clinical and laboratory standards Institute (CLSI) (2016): Performance standards for antimicrobial susceptibility testing; M100S $26^{\text {th }}$ ed

10. Collignon P.; Wegener H.C.; Braam P. and Butler C.D. (2005): The routine use of antibiotics to promote animal growth does little to benefit protein under nutrition in the developing world Clin. Infect. Dis. 41:1007-1013.

11. Dastmalchi S.H. and Ayremlou, N. (2012): Characterization of Shiga toxin-producing Escherichia coli (STEC) in feces of healthy and diarrheic calves in Urmia region, Iran. Iran J Microbiol. Jun; 4(2):63-9.

12. Deng Y.F. ; Y.J. Wang; Y. Zo, A.; Azarfar, X.L.; Wei, S.K. J. (2017): Influence of dairy by-product waste milk on the microbiomes of different gastrointestinal tract components in pre-weaned dairy calves. Sci. Rep., 7, p. 42689

13. El-Seedya, A. H. Abeda, H. A, Yannib, S. A., Abd El-Rahman B. (2016): Prevalence of Salmonella and E. coli in neonatal diarrheic calves, Beni-Suef University. Journal of Basic and Applied Sciences..11.010

14. El-Shehedi, M., A.; Mostafa, M. Eraqi and Aisha, R. Ali (2013): Characterization of Escherichia coli from diarrheic calves with special reference to plasmid profile Journal of American Science; 9(7): 54-59.

15. Finegold and Martin (1982): Bailey and Scott s. Diagnostic Microbiology. 6 th Ed. The C.V. Mosby Company. St. Louis, Toronto, London.

16. Astorga, F.; Navarrete- Tallonib, M.J.; Miród, M.P.; Toro V.B.M.; Blondel, C. J.; Hervé- Claudeac, L.P. (2019) Antimicrobial resistance in E. coli isolated from dairy calves and bedding material. J. Heliyon, 5 (11): e02773.

17. Fuente, R.; Garcia, S.; Orden, J.A.; Ruiz-Santa-Quiteria J.A.; Diez, R. and Cid, D. (2002): Prevalence and characteristics of attaching and effacing strains of Escherichia coli isolated from diarrheic and healthy sheep and goats. Am. J. Vet. Res.; 63(2):262-6. 
18. Patricia, G. M. and Robert, T. V. (1991): The Epidemiology of Infections Caused by Escherichia coli O157: H7, Other Enterohemorrhagic E. coli , and the Associated Hemolytic Uremic Syndrome. Epidemiologic Reviews, 13 : 60-98.

19. Gupta, M.D.; Sen, A. and Das, A. (2018 ): Occurrence of Escherichia coli carrying Shiga toxin-producing gene in buffaloe on small holdings in Bangladesh. Vet. World. 1111(10): 1454-1458.

20. Hakim, A.S.; Omara, S.T.; Syame, S.M. and Fouad, E.A. (2017): Serotyping, antibiotic susceptibility, and virulence genes screening of Escherichia coli isolates obtained from diarrheic buffalo calves in Egyptian farms. Vet. World; 10(7): 769-773.

21. Hosein, H.I. ( 2019): Virulence Profile of Enteropathogenic Escherichia coli $(\mathrm{Epec})$ Isolated From the Cases of Neonatal Calf Diarrhea . 10.17582/ journal. aavs/7.8.

22. Islam, A.A.; Rahman, M.; Nahar, A.; Abul Khair and Alam, M.M. (2015): Investigation of Pathogenic Escherichia Col from Diarrheic Calves in Selective Area of Bangladesh Bangladesh Journal of Veterinary Medicine 13(1):45-51

23. Izzo, M.M.; Izzo, P.D.; Kirkland, V.L.; Mohler, N.R.; Perkins, A.A. and Gunna, J.K. (2011): Prevalence of major enteric pathogens in Australian dairy calves with diarrhea. Aust Vet J, $89(5), 167-173$.

24. Karzmarczy, k.; Walsh, C.; Slowey, R.; Leonard, N. and Fanning, S. (2011): Molecular characterization of multidrug resistant Escherichia coli isolate from Irish Cattle Farms. Appl. Environ. Microbial., 77 (0): 7121-717.

25. Kohansal, M. and Aasd, G.A. (2018): Molecular analysis of shiga toxin-producing Escherichia coli O157:H7 and NonO157 strains isolated from calves. Onderstepoort Journal of Veterinary Research, 85(1):1621.

26. Kok, T.; Worswich, D. and Gowans, E. (1996): Some serological techniques for microbial and viral infections. In Practical Medical Microbiology (Collee, J.; Fraser, A.; Marmion, B. and Simmons, A., eds.), $14^{\text {th }}$ ed., Edinburgh, Churchill Livingstone, UK

27. Leão, C. ; Botelho, A. ; Martins, E.; Aguiar, C.; Rebelo, I. and Nunes, T. (2017): Presence of Mycobacterium avium subs. paratuberculosis DNA in milk used to feed calves in Portugal. J. Dairy Res., 84, 124-127

28. Masud, M.A.; Fakhruzzaman, M. and Nazir, H. (2012) Isolation of $E$. coli from apparently healthy and diarrheic calves in Bangladesh and their antibiogram. J. Bang Soc. Agric. Sci. Technol., 9, 45-48

29. Amer, M.M.; Mekky, H.M.; Amer, A.M. and Fedawy, H.S. (2018): Antimicrobial resistance genes in pathogenic Escherichia coli isolated from diseased broiler chickens in Egypt and their relationship with the phenotypic resistance characteristics. Vet World; 11(8): 1082-1088

30. Ibrahim, M.E.; Akeila, M.A. and Abd El-Rhem, S.M. (2008): Studies on Escherichia coli virulence factors coding heat stable toxin, Verotoxin and gene for attaching and effacing associating with diarrhea in calves using PCR. Minufiya Vet. J., 5 (1); 287-301.

31. Muluken, T.; Niguse, A.; Mu-uz, G.; Nirage, H.; Wassie, B.; Gashaw, B. and Birhanu, T. (2017): Major causes and risk factors associated with calf mortality in small scale dairy farms in gondar town Ethiopia Acad. J. Anim. Dis., 6 (3); 67-74.

32. Sunday, O. C.; Jeremiah, O.T.; Jubri, A.J. and Adewuyi, O.O (2016): Calf Diarrhea: Epidemiological Prevalence and Bacterial Load Oyo and Ogun States, Nigeri. Alexandria Journal of Veterinary Sciences, 51 (1): 90-96
33. Orden, J.A.; Ruiz-Santa-Quiteria, J.A.; Blanco, M.; Blanco, J.E.; Mora, A.; Cid, D.; González, E.A. and Blanco, J. (2003) Prevalence and characterization of Vero cytotoxin-producing Escherichia coli isolated from diarrhoeic and healthy sheep and goats, de la Fuente R. Epidemiol. Infect.; 130(2):313-21.

34. Osman, K.M.; Mustafa, A.M.; Elhariri, M. and Abdelhamed, G.S. (2013): The distribution of Escherichia coli serovars, virulence genes, gene association and combinations and virulence genes encoding serotypes in pathogenic E. coli recovered from diarrhoeic calves, sheep and goat. Transbound Emerg. Dis. 60 (1):69-78.

35. Pearce, M.C.; Jenkins, C.; Vali, L.; Smith, A.W.; Knight, H.L.; Cheasty, T.; Smith, H.R. and Gunn G.J. (2004): Temporal shedding patterns and virulence factors of Escherichia coli serogroups O26,O113,O111,O145 and O157 in Cohort of beef calves and dairy dams. Appl. Environ. Microbiol.; 136: 290294.

36. Quinn, P.J.; Markey, B.K.; Carter, M.E.; Donelly, W.J.C. and Leonard F.C. (2002): Veterinary microbiology and microbial diseases. Blackwell scientific publication, Oxford ,London. J.Anim. Sci. 85 (13); Suppl E45-E62.

37. Ruchi, T.; Sujata, B. and Anuradha, D. (2015): Comparison of phenotypic methods for the detection of biofilm production in uro-pathogens in a tertiary care hospital in India. Int. J. Curr. Microbial. App. Sci., 4:840-849.

38. Safaa, A. E.; Mohammed, S.; Abd El-Moneim, M.; Erfan, A.M.; Jakeen, K.; Abd El-Haleem, E.; Ashgan, M.; Hessainc T.M.; Dawoud, S. A. and Kablielhab, M. M. (2019): Risk factors associated with $E$. coli causing neonatal calf diarrhea. Saudi Journal of Biological Sciences, 1084-108

39. Sarmah, A.J.; Meyer, M.T. and Boxall A.B.A (2006): A global perspective on the use, sales, exposure pathways, occurrence, fate and effects of veterinary antibiotics in the environment. Chemosphere; $65: 72$

40. Shahrani, M.; Dehkordi, F.S. and Momtaz, H. (2014): Characterization of Escherichia coli virulence genes, pathotypes and antibiotic resistance properties in diarrheic calves in Iran. Biol Res. 23; 47:28

41. Srivani, M.; Redy, Y.N.; Subramanyam, K.V.; Reddy, M.R. And Rao, T.S. (2017): Prevalence and antimicrobial resistance pattrn of shiga toxin-producing Escherichia coli in diarrhic buffalo calves. Vet. Worled; 10(7): 774-778.

42. Sun, H.; Li.; Xie, Z.; Yang, F.; Sun, Y.; Zhu,Y.; Zhao, X. And Jiang, S. (2012): A novel multi drug resistance plamid isolated from an Escherichia coli strain resistant to Aminoglycoides. J. Antimicrob. Chmothr., 67:1635-1638.

43. Sundsfjord, A.; Simonsen, G.S.; Haldorsen, B.C.; Haaheim, H.; Hjelmevoll, S.; Littauer, P. and Dahi K.H. (2004): Genetic methods for detection of antimicrobial resistance. APMIS. 112: 815-37

44. Wang, Q.; Ruan, X. and Wei D. (2010): Development of a serogroup specific multiplex PCR assay to detect asset of $E$ coli serogroups based on the identification of their $\mathrm{O}$-antigen gene clusters. Molecular and cellular probes; 24 (5): 286-290

45. Yu, Q.H.; Wang, Z.S. and Yang, Q. (2011): Ability of Lactobacillus to inhibit enteric pathogenic bacteria adhesion on Caco-2 cells. World J. Microbiol. Biotechnol.; 27:881-886.

1. Yadegari,Z.; Brujeni, G.N.; Ghorbanpour, R.; Moosakhani, F. and Follahzadeh, S. (2019): Molecular characterization of enterotoxigenic Escherichia coli isolated from neonatal calves diarrhea. Vet. Res. Forum.; 10(1): 73-78. 